\title{
Cytokine expression in synovial tissue of psoriatic arthritis and its relationship with lymphoid neogenesis, disease activity and erosive disease: a longitudinal study
}

\author{
R Celis ${ }^{1^{*}}$, J Ramírez ${ }^{1}$, R Sanmartí ${ }^{1}$, J L Pablos², J D Cañete ${ }^{1}$ \\ From 5th European Workshop on Immune-Mediated Inflammatory Diseases \\ Sitges-Barcelona, Spain. 1-3 December 2010
}

\section{Objective}

To analyze the expression of cytokines in synovial tissue (ST) of patients with psoriatic arthritis (PsA) and their relationship with synovial lymphoid neogenesis (SLN) and disease activity at baseline, and with erosive disease at the end of follow-up.

\section{Methods}

ST samples from the inflamed knee joint of 30 patients fulfilling the CASPAR criteria for PsA were immunostained with CD3 (T cell), CD20 (B-cell) and MECA-79 (high endothelial vessels). SLN was defined by lymphoid aggregates grade 2-3 ( $>6$ radial of $\mathrm{B}$ and $\mathrm{T}$ cells), T-B cell segregation and MECA-79 positive vessels.

mRNA was also extracted from ST samples of patients and 2 controls without synovial inflammation, and measured by TaqMan. Relative changes in gene expression were assessed by the delta-delta CT method using GAPDH as an endogenous control gene. The following cytokines and receptors were analyzed: CCR7, Lymphotoxin (LT)-beta (b), IL-7, IL-10, IL-1b, IL-6, TNF-a, IL-17 A, IL-21, IL-22 and IL-23. Clinical and biological data were collected at inclusion and at the end of follow-up.

\section{Results}

Clinical and demographic data of patients are shown in Table 1.

LN. 12 out of 30 patients (40\%) had LN. These patients had higher mRNA expression of CCR7 and

${ }^{1}$ Unitat de Artritis, Servei de Reumatologia, Hospital Clinic e IDIBAPS,

Barcelona, Spain

Full list of author information is available at the end of the article
Table 1 Clinical and demographic data of PsA patients $(\mathbf{n}=30)$ at time of arthroscopy*

\begin{tabular}{lll}
\hline Age (years) at time of arthroscopy & 47 & $(37 ; 60)$ \\
Disease duration before arthroscopy (months) & 110 & $(30 ; 170)$ \\
Time of follow-up after arthroscopy (months) & 35 & $(22 ; 45)$ \\
Tender Joint Count & 2 & $(1 ; 2)$ \\
Swollen Joint Count & 2 & $(1 ; 3)$ \\
CRP (mg/dL) & 1.77 & $(0.30 ; 5.51)$ \\
ESR (mm/ ( $^{\text {st }}$ hour) & 18.5 & $(8 ; 52)$ \\
ACPA (UI/mIL) (n, positive $>25)$ & 0 & \\
Rheumatoid Factor (UI/ml) (n, positive $>20)$ & 2 & \\
DAS28 3v & 3.63 & $(2.73 ; 4.59)$ \\
Joint Pattern & & \\
$\quad$ Polyarthritis; $n(\%)$ & 11 & 36.7 \\
$\quad$ Oligoarthritis, $n(\%)$ & 19 & 63.3 \\
Type of Psoriasis & & \\
Type I (<40 years), $n(\%)$ & 22 & 70.3 \\
Type II (>40 years), $n(\%)$ & 8 & 29.7 \\
\hline
\end{tabular}

*Data are expressed as median and IQR. CRP: C-reative protein; ESR: erythrocyte sedimentation rate; ACPA: anti-citrullinated peptide/protein antibodies; DAS: disease activity score.

LT-b than patients without LN $(\mathrm{p}<0.005$ and $\mathrm{p}<0.04$, respectively). In addition, LN-positive patients had a strong trend to significantly higher IL-23 $(\mathrm{p}=0.051)$ and TNF-a $(\mathrm{p}<0.08)$ expression.

Disease activity. We found a positive correlation between IL-6 expression and SJC, CRP and DAS28 at baseline ( $\mathrm{p}=0.02, \mathrm{p}=0.001$ and $\mathrm{p}=0.034$, respectively) and between IL-1b expression and CRP levels at baseline $(\mathrm{p}=0.015)$. We also found a negative correlation between IL-10 expression and ESR levels at inclusion $(\mathrm{p}=0.008)$. Erosive disease. 15 out of 30 (50\%) patients had erosive 
disease at the end of follow-up. These patients had a trend to higher IL-6 $(\mathrm{p}<0.15)$.

\section{Conclusion}

PsA patients with SLN have a different profile of cytokine expression in ST compared with patients without LN, although we found no clinical differences between both groups probably due to the small sample size. IL-6 expression correlated positively with disease activity and systemic inflammation at baseline, whereas IL-1b correlated positively, and IL-10 negatively, with markers of inflammation.

\section{Author details}

${ }^{1}$ Unitat de Artritis, Servei de Reumatologia, Hospital Clinic e IDIBAPS,

Barcelona, Spain. '2Unidad de Investigación, Servicio de Reumatología,

Hospital 12 de Octubre, Madrid, Spain.

Published: 25 November 2010

doi:10.1186/1479-5876-8-S1-P58

Cite this article as: Celis et al:: Cytokine expression in synovial tissue of psoriatic arthritis and its relationship with lymphoid neogenesis, disease activity and erosive disease: a longitudinal study. Journal of Translational Medicine 2010 8(Suppl 1):P58.

Submit your next manuscript to BioMed Central and take full advantage of:

- Convenient online submission

- Thorough peer review

- No space constraints or color figure charges

- Immediate publication on acceptance

- Inclusion in PubMed, CAS, Scopus and Google Scholar

- Research which is freely available for redistribution

Submit your manuscript at www.biomedcentral.com/submit 